Sitasi artikel ini (APA $6^{\text {th }}$ Edition style):

Sembiring, S. Br. (2019). Meningkatkan Minat Belajar Siswa pada Kompetensi Dasar Politik Luar Negeri Mata Pelajaran PKN Melalui Penggunaan Model Pembelajaran Kooperatif Tipe Tari Bambu Kelas VIB SD Negeri 060930 Medan Johor. MUKADIMAH, 2(2), 42-57.

\title{
MENINGKATKAN MINAT BELAJAR SISWA PADA KOMPETENSI DASAR POLITIK LUAR NEGERI MATA PELAJARAN PKN MELALUI PENGGUNAAN MODEL PEMBELAJARAN KOOPERATIF TIPE TARI BAMBU KELAS VIB SD NEGERI 060930 MEDAN JOHOR
}

\author{
Sorita Br Sembiring, S.Pd \\ Guru SD NEGERI 060930 Medan Johor
}

\begin{abstract}
ABSTRAK
Penelitian ini bertujuan untuk mengetahui apakah dengan menggunakan model pembelajaran kooperatif tipe tari bambu dapat meningkatkan minat belajar siswa pada mata pelajaran PKn di Kelas VIB SD Negeri 060930 Medan Johor T.A 2014/2015. Jenis penelitian ini adalah “Penelitian Tindakan Kelas", dengan menggunakan model pembelajaran kooperatif tipe tari bambu. Penelitian ini bertujuan untuk mengetahui bahwa dengan menggunakan model pembelajaran kooperatif tipe tari bambu dapat meningkatkan minat belajar siswa pada pokok bahasan politik luar negeri di Kelas VIB SD Negeri 060930 Medan Johor. Penelitian ini terdiri dari 2 siklus, siklus I dan siklus II masing-masing memiliki 2 pertemuan. Pada setiap pertemuan peneliti melakkukan observasi belajar terhadap siswa, untuk mengetahui tingkat minat belajar siswa. Berdasarkan hasil observasi yang dilakukan penulis dengan guru Kelas VIB SD Negeri 060930 Medan Johor yang dilakukan terhadap 30 orang siswa terdapat 24 orang siswa $(80 \%)$ yang memiliki minat belajar yang kurang dan 6 orang siswa (20\%) yang memiliki minat yang cukup. Kemudian pada siklus I memiliki nilai rata-rata $44(55 \%)$, sedangkan pada siklus II yaitu sebesar 69 (87\%). Berdasarkan hasil penelitian dari tes siklus I dengan siklus II terjadi peningkatan yang signifikan, dengan demikian dapat disimpulkan bahwa dengan menerapkan model pembelajaran kooperatif tipe tari bambu dapat meningkatkan minat belajar siswa pada mata pelajaran PKn pokok bahasan politik luar negeri di Kelas VIB SD Negeri 060930 Medan Johor. Tahun Ajaran 2014/2015.
\end{abstract}

Kata Kunci: Minat Belajar, Pembelajaran Kooperatif.

\section{PENDAHULUAN}

Masalah pendidikan merupakan masalah yang sangat penting, karena pendidikan itu akan sangat berpengaruh terhadap perkembangan hidup manusia. Dengan semakin tingginya jenjang pendidikan yang ditempuh seseorang maka semakin besar pula kesempatan untuk meraih sukses hidup di masa mendatang. Secara garis besarnya, pendidikan sangat berkompeten 
dalam kehidupan, baik kehidupan diri sendiri, keluarga, masyarakat, maupun kehidupan bangsa dan negara.

Untuk mencapai tujuan tersebut, pemerintah mendirikan lembaga pendidikan salah satunya adalah Sekolah. Sekolah sebagai tempat proses belajar mengajar mempunyai kedudukan yang sangat penting dalam dunia pendidikan. Oleh karena itu pendidikan di sekolah memegang peranan penting dalam rangka mewujudkan tercapainya pendidikan nasional secara optimal seperti yang diharapkan untuk mencerdaskan anak bangsa. Belajar adalah key term (istilah kunci) yang paling vital dalam setiap usaha pendidikan, sehingga tanpa belajar sesungguhnya tidak pernah ada pendidikan. Sebagai suatu proses, belajar hampir selalu mendapat tempat yang luas dalam berbagai disiplin ilmu yang berkaitan dengan upaya kependidikan.

Minat adalah suatu rasa lebih suka dan rasa keterikatan pada suatu hal atau aktivitas, tanpa ada yang menyuruh. Minat pada dasarnya adalah penerimaan akan suatu hubungan antara diri sendiri dengan sesuatu di luar diri. Semakin kuat atau dekat hubungan tersebut, semakin besar minat. Suatu minat dapat diekspresikan melalui suatu pernyataan yang menunjukkan bahwa siswa lebih menyukai suatu hal daripada hal lainnya, dapat pula dimanifestasikan melalui partisipasi dalam suatu aktivitas. Minat tidak dibawa sejak lahir, melainkan diperoleh kemudian. Siswa yang memiliki minat terhadap subyek tertentu cenderung untuk memberikan perhatian yang lebih besar terhadap subyek tersebut.

Salah satu upaya yang dapat dilakukan untuk meningkatkan minat belajar siswa adalah dengan menggunakan model pembelajaran yang menarik bagi siswa. Selain itu model pembelajaran yang menunjang aktifitas siswa belajar dengan model pembelajaran yang aktif dan tidak monoton akan membantu meningkatkan minat belajar siswa. Salah satunya adalah dengan menggunakan model pembelajaran kooperatif tipe tari bambu.

Teknik ini diberi nama Tari Bambu, karena siswa berjajar dan saling berhadapan dengan model yang mirip seperti dua potong bambu yang digunakan dalam Tari Bambu Filipina yang juga popular di beberapa daerah di Indonesia. Dalam kegiatan belajar mengajar dengan teknik ini, siswa saling berbagi informasi pada saat yang bersamaan. Pendekatan ini bisa digunakan dalam beberapa mata pelajaran, seperti ilmu pengetahuan sosial, agama, matematika, dan bahasa. Bahan pelajaran yang paling cocok digunakan dengan teknik ini adalah bahan yang membutuhkan pertukaran pengalaman, pikiran, dan informasi antarsiswa. Salah satu keunggulan teknik ini adalah adanya struktur yang jelas dan memungkinkan siswa untuk berbagi dengan pasangan yang berbeda dengan singkat dan teratur. Selain itu, siswa bekerja dengan sesama siswa dalam suasana gotong royong dan mempunyai banyak kesempatan untuk mengolah informasi dan meningkatkan keterampilan 
berkomunikasi. Tari bambu bisa digunakan untuk semua tingkatan usia anak didik.

Mengembangkan minat terhadap sesuatu pada dasarnya adalah membantu siswa melihat bagaimana hubungan antara materi yang diharapkan untuk dipelajarinya dengan dirinya sendiri sebagai individu. Proses ini berarti menunjukkan pada siswa bagaimana pegetahuan atau kecakapan tertentu mempengaruhi dirinya, melayani tujuan-tujuannya, memuaskan kebutuhankebutuhannya. Bila siswa menyadari bahwa belajar merupakan suatu alat untuk mencapai beberapa tujuan yang dianggapnya penting dan bila siswa melihat bahwa hasil dari pengalaman belajarnya akan membawa kemajuan pada dirinya, kemungkinan besar ia akan berminat (dan bermotivasi) untuk mempelajarinya.

Model pembelajaran kooperatif tipe tari bambu merupakan model pembelajaran yang tepat dipilih dan dipergunakan untuk meningkatkan minat belajar siswa. Dalam metode ini siswa bermain seperti yang dialami dalam kehidupan mereka sehari-hari sehingga penerapan metode ini siswa lebih aktif dalam mengikuti pelajaran.

\section{METODE}

Dalam penelitian ini penulis menggunakan jenis penelitian tindakan kelas (PTK) yang bertujuan untuk memperbaiki proses pembelajaran dalam meningkatkan minat belajar PKn siswa dengan menggunakan model pembelajaran kooperatif tipe tirai bambu. Proses penelitian seperti gambar berikut :

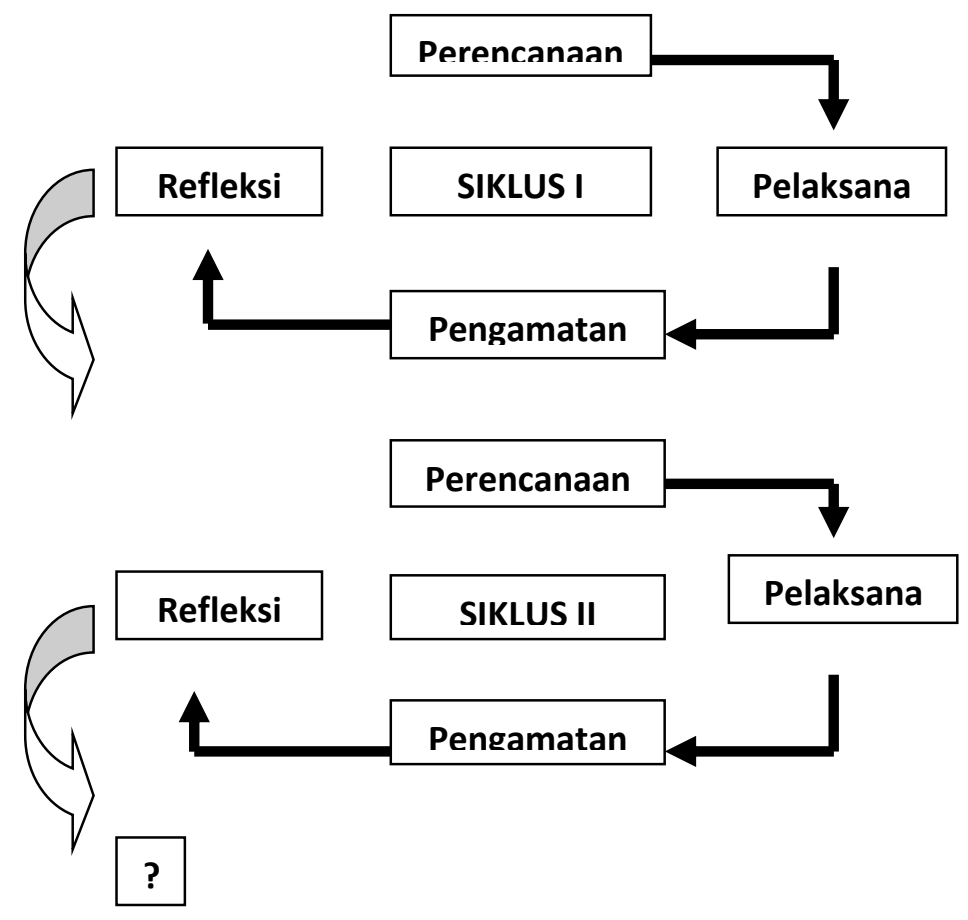

Gambar 1. Skema Pelaksanaan Tindakan Kelas (PTK). 
Sesuai dengan jenis penelitian ini, yaitu penelitian tindakan kelas, maka penelitian ini memiliki beberapa tahap yang merupakan suatu siklus. Tiap siklus dilaksanakan sesuai dengan perubahan yang dicapai. Pada penelitian ini akan dilaksnakan dua siklus, yaitu : Siklus I dilaksanakan dengan menggunakan Tes awal. Tes awal diberikan untuk mengetahui bagaimana minat belajar siswa dalam politik luar negeri Indonesia. Sebelum pelaksanaan siklus I siswa diberi tes terlebih dahulu, untuk mengetahui letak kesulitan masing-masing siswa. Selain itu, pada siklus I dilakukan juga observasi dan evaluasi terhadap siswa. Dari observasi dan evaluasi maka dilakukan refleksi tehadap pemberian tindakan pada siklus I yang dijadikan sebagai pedoman pelaksanaan siklus I.

Apabila pada siklus I minat belajar siswa dalam politik luar negeri belum menujukkan ketuntasan maka dilanjutkan dengan siklus berikutnya. Adapun prosedur dilaksankan sebagai berikut: (1) perencanaan, (2) pelaksanaan, (3) observasi, (4) refleksi, yang dilaksanakan dalam setiap siklus.

\section{Siklus I}

\section{Perencanaan}

Sebelum melakukan kegiatan guru melakukan persiapan demi kelancaran pelaksanaan penelitian tindakan kelas ini. Permasalahan yang diidentifikasi pada pembelajaran PKn yang terkait dengan meningkatkan minat belajar pada siswa Kelas VIB SD Negeri 060930 Medan Johor, diusahakan pemecahan dengan menerapkan model pembelajaran kooperatif tipe tari bambu. Sesuai dengan metode pembelajaran yang dipilih, maka perencaanperencaan oleh guru bersama guru dilakukan pada tahap seperti berikut ini yaitu :

a. Menyusun persiapan mengajar rencana pelaksaan pembelajaran (RPP) sesuai dengan pokok bahasan yang akan diajarkan pada setiap pertemuan

b. Memberi penjelasan dan melatih guru mengenai penerapan model pembelajaran kooperatif tipe tari bambu

c. Menyiapkan materi pelajaran yang akan dibagikan kepada siswa sebagai bahan pelajaran bagi siwa dalam politik luar negeri untuk mengetahui tingkat keberhasilan yang dicapai siswa dengan diterapkannya model pembelajaran kooperatif tipe tari bambu

d. Menyiapkan sumber belajar berupa buku pelajaran PKn Kelas VI.

e. Membuat lembar observasi guna mengamati proses pembelajaran.

\section{Pelaksanaan}

Dalam pelaksanaan PTK, istilah dipahami aktivitas yang dirancang dengan sistematis untuk menghasilkan adanya peningkatan atau perbaikan dalam proses pembelajaran. Dalam melaksanakan tindakan maka perlu 
menyusun langkah-langkah oprasional atau skenario pembelajaran dari tindakan yang dilakukan dengan memperlihatkan tindakan yang ingin diterapkan yaitu model pembelajaran kooperatif tipe tari bambu. Pelaksanaan tindakannya yaitu :

a) Pendahuluan

1. Guru mengucapkan salam pembuka

2. Guru membuka pelajaran dengan cara mengabsensi kehadiran siswa

3. Guru melakukan apersepsi terhadap materi yang akan disampaikan dengan mengadakan motivasi kepada siswa

4. Guru menyampaikan tujuan pembelajaran

b) Kegiatan Inti

1. Guru menjelaskan materi pelajaran yaitu politik luar negeri

2. Guru menjelaskan aturan-aturan dalam politik luar negeri tersebut

3. Guru memberikan petunjuk kepada siswa tentang politik luar negeri

4. Siswa diberi waktu untuk memahami tentang politik luar negeri tersebut

5. Siswa diberi waktu untuk politik luar negeri dengan kata - katanya sendiri tanpa ada bantuan dari temannya

6. Guru membagi siswa menjadi 3 kelompok yang terdiri dari 5 pasang tiap kelompoknya

7. Guru menyuruh siswa untuk duduk berjajar di kursi yang telah disusun sebelumnya sesuai dengan kelompoknya masing - masing

8. Guru mengarahkan siswa yang berpasangan dari kedua jajaran berbagi informasi tentang materi yang telah disusunnya dengan kata - katanya sendiri yang telah di berikan dan kemudian, satu atau dua siswa yang berdiri di ujung salah satu jajaran pindah ke ujung lainnya di jajarannya. Jajaran ini kemudian bergeser. Dengan cara ini, masing-masing siswa mendapatkan pasangan yang baru untuk berbagi. Pergeseran bisa dilakukan terus menerus sesuai dengan kebutuhan guru

9. Guru memonitor jalannya model pembelajaran kooperatif tipe tari bambu

10. Guru melaksanakan tes tertulis dan lisan. Dimana tes tertulis, guru menilai hasil tulisan siswa dalam politik luar negeri dengan kata katanya sendiri dan tes lisan dimana guru melihat interaksi siswa dengan siswa lainnya. Tes ini bersifat individual

c) Penutup

1. Guru memberi masukan tentang model pembelajaran kooperatif tipe tari bambu yang dilakukan oleh siswa 


\section{Pengamatan}

Kegiatan yang dilakukan pada tahap ini adalah :

a. Observasi dilaksanakan untuk mengamati proses pembelajaran di kelas secara langsung dengan dibantu guru kelas. Kegiatan yang diamati meliputi aktivitas guru dan anak didik dalam proses pembelajaran. Observasi ini berguna mengetahui sejauh mana pelaksanaan tindakan dapat menghasilkan perubahan sesuai dengan yang dikehendaki.

b. Melaksanakan evaluasi untuk mengukur hasil belajar siswa sesudah diterapkan tindakan. Evaluasi ini dilakukan dengan menggunakan tes hasil belajar PKn.

\section{Refleksi}

Refleksi dilakukan berdasarkan hasil analisa data observasi di dalam kelas dan tes hasil belajar siswa. Refleksi ini dilakukan mengarahkan kepada perbaikan-perbaikan tindakan selanjutnya. Refleksi ini dilakukan untuk menganalisa perbaikan makna terhadap kesimpulan dari tindakan perbaikan yang telah dilakukan. Hasil refleksi ini kemudian digunakan sebagai dasar untuk tahap perencanaan pada siklus selanjutnya.

Setelah siklus I dilakukan dan sebelum menunjukkan hasil pada kemampuan siswa dalam meningkatkan minat belajar siswa dalam politik luar negeri. Maka dalam hal ini dilaksanakan siklus II dengan tahapan yang sama sebagai berikut:

\section{Siklus II}

\section{Perencanaan}

Pada siklus I direncanakan melaksankan kembalai program siklus II dengan terlebih dahulu mengidentifikasi kelemahan-kelemahan yang terdapat pada siswa di siklus I. Adapun rencana kegiatan pada tahap ini adalah:

a. Mengidentifikasi kelemahan pembelajaran selama siklus I

b. Menyusun persiapan mengajar rencana pelaksaan pembelajaran (RPP) sesuai dengan pokok bahasan yang akan diajarkan pada setiap pertemuan

c. Memberi penjelasan dan melatih guru mengenai penerapan model pembelajaran kooperatif tipe tari bambu

d. Menyuruh siswa untuk politik luar negeri dengan menggunakan katakatanya sendiri berdasarkan materi yang diberikan yang telah di berikan. 
e. Menyusun siswa untuk berjajar berkelompok seperti pada kegiatan inti siklus I, untuk mengetahui tingkat keberhasilan yang dicapai siswa dengan diterapkannya model pembelajaran kooperatif tipe tari bambu

f. Menyiapkan sumber belajar berupa buku pelajaran PKn Kelas VI

g. Membuat lembar observasi guna mengamati proses pembelajaran

\section{Pelaksanaan}

Pada tahap kegiatan ini, kegiatan yang dilaksanakan adalah sama seperti pada siklus I yaitu dengan menggunakan model pembelajaran kooperatif tipe tari bambu juga, yaitu :

a. Guru mengarahkan siswa untuk lebih berani dalam berinteraksi dengan teman yang lain, bertukar informasi, politik luar negeri dengan katakata sendiri dengan susunan kata-kata yang baik dan tepat

b. Guru memberikan motivasi dan penguatan agar siswa tidak merasa takut dan percaya diri untuk ke depan kelas pada saat memulai kegiatan belajar mengajar dengan menggunakan model pembelajaran tipe tari bambu

c. Sebelum masuk ke materi guru terlebih dahulu memberikan petunjuk kepada siswa tentang tata cara bertukar informasi dengan menggunakan model pembelajaran kooperatif tipe tari bambu.

d. Guru membagi kelompok dengan berjajar seperti pada siklus I.

e. Guru memberikan masukan tentang pembelajaran yang telah dilakukan siswa dengan menggunakan model pembelajaran tipe tari bambu.

f. Melaksanakan kegiatan sesuai dengan skenario pembelajaran atau Rencana Pelaksanaan Pembelajaran (RPP).

a) Pendahuluan

1. Guru mengucapkan salam pembuka.

2. Guru membuka pelajaran dengan cara mengabsensi kehadiran siswa.

3. Guru melakukan apersepsi terhadap materi yang akan disampaikan dengan mengadakan motivasi kepada siswa.

4. Guru menyampaikan tujuan pembelajaran.

b) Kegiatan Inti

1. Guru menjelaskan materi pelajaran yaitu politik luar negeri .

2. Guru menjelaskan aturan-aturan dalam politik luar negeri tersebut.

3. Guru memberikan petunjuk kepada siswa tentang politik luar negeri .

4. Siswa diberi waktu untuk memahami tentang politik luar negeri tersebut.

5. Siswa diberi waktu untuk politik luar negeri dengan kata-katanya sendiri tanpa ada bantuan dari temannya. 
6. Guru membagi siswa menjadi separuh kelas (atau seperempat jika jumlah siswa terlalu banyak) untuk berdiri berjajar.

7. Guru menyuruh siswa untuk mereka bisa berjajar di depan kelas atau siswa berjajar di sela-sela deretan bangku.

8. Guru menyuruh separuh kelas lainnya berjajar dan menghadap jajaran yang pertama.

9. Guru mengarahkan siswa yang berpasangan dari kedua jajaran berbagi informasi tentang materi pelajaran, satu atau dua siswa yang berdiri di ujung salah satu jajaran pindah ke ujung lainnya di jajarannya. Jajaran ini kemudian bergeser. Dengan cara ini, masing-masing siswa mendapatkan pasangan yang baru untuk berbagi. Pergeseran bisa dilakukan terus menerus sesuai dengan kebutuhan guru.

10. Guru memonitor jalannya model pembelajaran kooperatif tipe tari bambu.

11. Guru melaksanakan tes tertulis dan lisan. Dimana tes tertulis, guru menilai hasil tulisan siswa dalam politik luar negeri dengan katakatanya sendiri dan tes lisan dimana guru melihat interaksi siswa dengan siswa lainnya. Tes ini bersifat individual.

c) Penutup, yaitu guru memberi masukan tentang model pembelajaran kooperatif tipe tari bambu yang dilakukan oleh siswa.

\section{Pengamatan}

Seperti pada siklus I, observasi dilakukan untuk melihat perubahanperubahan yang terjadi pada siswa dengan adanya penggunaan model pembelajaran kooperatif tipe tari bambu. Kemudian pada siklus II ini dilakukan untuk mengetahui minat belajar siswa terhadap materi politik luar negeri dengan kata - kata sendiri, dengan menggunakan model pembelajaran kooperatif tipe tari bambu. Guru sebagai observer mengamati kegiatan selama proses pembelajaran berlangsung dengan berpedoman pada lembar observasi. Hasil obervasi ini ditindak lanjuti analisis untuk bahan refleksi.

\section{Refleksi}

Refleksi dilakukan pada akhir siklus II. Kegiatan ini dilakukan untuk melihat hasil perkembangan pelaksaan dan membuat kesimpulan mengenai kekurangan dan kelebihan yang telah dilakukan.

Teknik Analisis Data

- Klasikal 
Analisis ini digunakan untuk mengetahui berhasil atau tidaknya tindakan yang dilakukan dengan menggunakan rumus untuk variabel minat, menurut Rosmala Dewi (2009:114) adalah sebagai berikut :

Keterangan :

$\mathrm{P}=$ Angka minat

$\mathrm{F}=$ Jumlah siswa yang mengalami perubahan

$\mathrm{N}=$ Jumlah seluruh siswa

- Individu

Untuk menghitung data individu, menurut Muslich (2011:161), maka digunakan rumus :

Kriteria untuk menentukan keberhasilan tindakan dalam minat belajar siswa sebagai berikut :

1. Sangat berminat : $86 \%-100 \%$, dari jumlah siswa tiap indikator.

2. Berminat $: 71 \%-85 \%$, dari jumlah siswa tiap indikator.

3. Cukup berminat $: 60 \%-70 \%$, dari jumlah siswa tiap indikator.

4. Kurang berminat $:<60 \%$, dari jumlah siswa tiap indikator.

\section{HASIL DAN PEMBAHASAN}

\section{Siklus I}

\section{Perencanaan}

Guru mempersiapkan siklus I dengan beberapa kegiatan dalam pembelajaran dan instrumen penelitian siswa dengan menerapkan pembelajaran yang menggunakan model pembelajaran kooperatif tipe tari bambu dengan membagi siswa dalam kelompok belajar.

Adapun Standar Kompetensi (SK) yang dibahas dalam kegiatan pembelajaran tersebut adalah memahami politik luar negeri. Dengan kompetensi Dasar (KD) menanggapi politik luar negeri disampaikan secara lisan serta menyusun kelompok belajar siswa.

Langkah-langkah yang disusun dalam RPP dengan menggunakan model pembelajaran kooperatif tipe tari bambu, dimana model pembelajaran ini akan mengaktifkan siswa untuk mempelajari dan mengerjakan latihan baik secara individu maupun berkelompok. Sedangkan instrumen penelitian adalah lembar observasi. Pada siklus ini dilakukan 2 kali pertemuan, pertemuan berlangsung selama 4 jam pelajaran (4 x 35 menit). 


\section{Pelaksanaan}

Pada kegiatan ini guru menerapkan penggunaan model pembelajaran kooperatif tipe tari bambu yang bertujuan untuk meningkatkan minat belajar siswa pada mata pelajaran PKn pokok bahasan politik luar negeri, dengan alokasi waktu 2 x 35 menit (kegiatan awal 10 menit, kegiatan inti 50 menit, dan kegiatan akhir 10 menit).

Adapun kegiatan pembelajaran sesuai dengan skenario pembelajaran yang telah disusun adalah sebagai berikut : mengucapkan salam pembuka, mengkondisikan ruang belajar (kelas), mengabsen siswa, melakukan appersepsi, memotivasi siswa, menjelaskan konsep-konsep pelajaran yang akan dipelajari, selanjutnya guru membuka pelajaran dengan menyampaikan rancangan materi politik luar negeri melalui penggunaan model pembelajaran kooperatif tipe tari bambu yang bertujuan untuk meningkatkan minat belajar siswa. Dengan menggunakan model pembelajaran kooperatif tipe tari bambu ini, siswa akan berminat, aktif, sehingga akan berdampak pada hasil belajar siswa dan membantu siswa mengetahui apa yang harus dan apa yang tidak harus dilakukan dalam kegiatan pembelajaran.

Kegiatan yang dilakukan untuk peningkatan minat belajar siswa adalah membagi peserta didik menjadi beberapa kelompok secara heterogen agar merata antara kemampuan masing-masing peserta didik, memberikan informasi kepada siswa bagaimana prosedur model pembelajaran kooperatif tipe tari bambu, menjelaskan materi pelajaran yaitu politik luar negeri dengan kalimatnya sendiri, dengan jelas dan singkat. Selanjutnya guru meminta peserta didik untuk melakukan pemahaman tentanng materi politik luar negeri dengan kalimatnya sendiri, kemudian guru membimbing peserta didik selama proses belajar mengajar.

Setelah peserta didik menyelesaikan tugasnya untuk politik luar negeri dengan waktu yang telah ditentukan oleh guru, kemudian peserta didik didorong untuk saling bertukar informasi tentang hasil tulisannya kepada teman yang berada dihadapannya berdasarkan kelompok yang telah disusun dengan waktu yang telah ditentukan oleh guru. Selanjutnya guru memberikan kesempatan kepada peserta didik untuk bertanya tentang hal-hal yang kurang dimengerti peserta didik pada materi pelajaran politik luar negeri, serta menjelaskan kembali secara singkat, guru bertanya-jawab dengan peserta didik tentang seputar materi pelajaran politik luar negeri dan bersama-sama dengan peserta didik membuat kesimpulan.

\section{Pengamatan}

Pada tahap ini, guru bersama guru kelas melakukan observasi guru dan observasi siswa dengan menggunakan alat bantu check list terhadap pelaksanaan kegiatan pembelajaran berlangsung yang menggunakan metode 
pemberian tugas. Pada saat pembelajaran berlangsung, obsever melakukan observasi terhadap guru, obsever dan guru melakukan observasi perilaku belajar siswa terhadap minat belajar siswa. Setelah pelaksanaan siklus I berakhir, guru memberikan evaluasi belajar untuk menambah penguatan dalam dalam mengetahui minta belajar siswa dan keberhasilan metode pemberian tugas yangn digunakan.

Selama pengamatan, banyak hal yang diperoleh antara lain: 1) siswa belum dapat berinteraksi dengan guru maupun berinteraksi dengan temanteman sekelas, 2) pada kegiatan ini, ada beberapa siswa yang masih enggan untuk mengemukakan pendapatnya, 3) pada kegiatan ini, masih ditemukan siswa yang lebih mementingkan bermain dari pada langsung mengerjakan tugas yang diberikan, sehingga mereka tidak dapat menyelesaikan tugas yang diberikan dengan tepat waktu, 4) guru kurang menguasai kelas, 5) ada beberapa siswa yang sama sekali tidak mengerjakan tugas yang diberikan oleh guru, 6) siswa belum aktif dalam menyelesaikan tugas yang telah diberikan.

\section{Refleksi}

Hasil observasi siklus I yang dilakukan oleh guru dari 30 jumlah siswa, yakni diperoleh nilai sebagai berikut : Siswa yang kurang berminat sebanyak 24 orang dengan persentase $80 \%$. Dari hasil observasi siswa yang telah dilakukan pada siklus I, maka guru melakukan refleksi pada siklus I yang hasilnya adalah: 1) guru kurang menguasai kelas dengan baik, 2) siswa belum aktif dalam menjawab / menyelesaikan tugas yang diberikan guru, karena guru kurang menguasai model pembelajaran, 2) di dalam proses pembelajaran, guru belum dapat menggunakan waktu yang efektif sehingga tujuan pembelajaran belum tercapai, 3) aktivitas guru dalam bertanya kepada siswa, memperhatikan dan membimbing siswa harus lebih ditingkatkan lagi, 4) tahap kegiatan akhir, guru diharapkan dapat melaksanakan penilaian pembelajaran dan lebih sempurna lagi dalam merangkum isi pelajaran, 5) lebih memfokuskan menyelesaikan tugas siswa dalam menyelesaikan soal, serta saling berinteraksi mengeluarkan pendapat tentang materi dengan teman dalam kelompoknya.

\section{SIKLUS II}

\section{Perencanaan}

Tahap perencanaan pada siklus II merupakan hasil refleksi dari siklus I dimana hasil pada siklus I belum mencapai tujuan yang telah ditetapkan. Pada tahap siklus II ini guru membuat perencanaan tindakan untuk meningkatkan kemampuan siswa dalam menyelesaikan soal.

Adapun Standar Kompetensi (SK) yang dibahas dalam kegiatan pembelajaran tersebut adalah memahami tentang politik luar negeri. Dengan kompetensi Dasar (KD) menanggapi tentang politik luar negeri serta menyusun kelompok belajar siswa. 
Langkah-langkah yang disusun dalam RPP dengan menggunakan model pembelajaran kooperatif tipe tari bambu, dimana model pembelajaran ini akan mengaktifkan siswa untuk mempelajari dan mengerjakan latihan baik secara individu maupun berkelompok. Sedangkan instrumen penelitian adalah lembar observasi. Pada siklus ini dilakukan 2 kali pertemuan, pertemuan berlangsung selama 4 jam pelajaran (4 × 35 menit).

\section{Pelaksanaan}

Pada kegiatan ini guru menerapkan penggunaan model pembelajaran kooperatif tipe tari bambu yang bertujuan untuk meningkatkan minat belajar siswa pada mata pelajaran PKn pokok bahasan politik luar negeri, dengan alokasi waktu 2 x 35 menit (kegiatan awal 10 menit, kegiatan inti 50 menit, dan kegiatan akhir 10 menit).

Adapun kegiatan pembelajaran sesuai dengan skenario pembelajaran yang telah disusun adalah sebagai berikut: mengucapkan salam pembuka, mengkondisikan ruang belajar (kelas), mengabsen siswa, melakukan appersepsi, memotivasi siswa, menjelaskan konsep-konsep pelajaran yang akan dipelajari, selanjutnya guru membuka pelajaran dengan menyampaikan rancangan materi politik luar negeri melalui penggunaan model pembelajaran kooperatif tipe tari bambu yang bertujuan untuk meningkatkan minat belajar siswa. Dengan menggunakan model pembelajaran kooperatif tipe tari bambu ini, siswa akan berminat, aktif, sehingga akan berdampak pada hasil belajar siswa dan membantu siswa mengetahui apa yang harus dan apa yang tidak harus dilakukan dalam kegiatan pembelajaran.

Setelah peserta didik menyelesaikan tugasnya untuk politik luar negeri berdasarkan dengan waktu yang telah ditentukan oleh guru, kemudian peserta didik didorong untuk saling bertukar informasi tentang hasil tulisannya kepada teman yang berada di hadapannya berdasarkan kelompok yang telah disusun dengan waktu yang telah ditentukan oleh guru.

Selanjutnya guru memberikan kesempatan kepada peserta didik untuk bertanya tentang hal-hal yang kurang dimengerti peserta didik pada materi pelajaran politik luar negeri, serta menjelaskan kembali secara singkat, guru bertanya-jawab dengan peserta didik tentang seputar materi pelajaran politik luar negeri dan bersama-sama dengan peserta didik membuat kesimpulan.

\section{Pengamatan}

Pada tahap ini, guru kelas melakukan observasi guru dan observasi siswa dengan menggunakan alat bantu check list terhadap pelaksanaan kegiatan pembelajaran berlangsung yang menggunakan metode pemberian tugas. Pada saat pembelajaran berlangsung, obsever melakukan observasi terhadap guru, obsever dan guru melakukan observasi perilaku belajar siswa terhadap minat belajar siswa. Setelah pelaksanaan siklus II berakhir, guru 
memberikan evaluasi belajar untuk menambah penguatan dalam dalam mengetahui minta belajar siswa dan keberhasilan metode pemberian tugas yang digunakan.

Selama observasi banyak hal yang diperoleh antara lain: 1) siswa cepat berinteraksi dengan guru maupun berinteraksi dengan teman-teman sekelas, 2) pada tahap ini siswa tidak enggan lagi untuk mengemukakan pendapatnya, 3) siswa selalu mengikuti kegiatan pembelajaran dengan penuh semangat tinggi dan tidak cepat putus asa dalam mengerjakan tugas yang diberikan oleh guru, 4) guru sudah dapat menguasai kelas dengan baik, 5) pada kegiatan ini siswa sudah langsung mengerjakan tugas yang diberikan, sehingga mereka telah bertanggung jawab dengan tugas yang deiberikan, 6) siswa sudah aktif dalam politik luar negeri melalui gambar yang ditunjukkan kepadanya.

Tabel 1.

Siswa yang Aktif Selama Siklus II

\begin{tabular}{|c|c|c|l|}
\hline Keaktifan & $\mathrm{F}$ & $\%$ & Keterangan \\
\hline $86 \%-100 \%$ & 20 & 67 & Sangat Berminat \\
\hline $71 \%-85 \%$ & 10 & 33 & Berminat \\
\hline $60 \%-70 \%$ & - & - & Cukup Berminat \\
\hline$<60 \%-$ & - & - & Kurang Berminat \\
\hline Jumlah & 30 & 100 & \\
\hline
\end{tabular}

Berdasarkan Tabel 4.3 di atas dapat dinyatakan bahwa hasil observasi siklus II yang dilakukan oleh guru dari 30 jumlah siswa, yakni diperoleh nilai sebagai berikut:

a) Siswa yang sangat berminat sebanyak 20 orang dengan persentase $67 \%$.

b) Siswa yang berminat sebanyak 10 orang dengan persentase $33 \%$.

Data dari hasil observasi siswa pada siklus II dapat diketahui bahwa minat belajar siswa Kelas VIB SD Negeri 060930 Medan Johor, dapat dikatakan sudah lebih meningkat. Hal ini dapat dilihat dari data observasi siswa yang berdasarkan dari indikator minat, yaitu:

1) Observasi siswa mengenai minat mengikuti pelajaran terdiri dari 4 deskriptor, yaitu siswa memperhatikan guru mengajar sebanyak 29 siswa $(97 \%)$, siswa tidak ribut pada saat pembelajaran berlangsung sebanyak 25 siswa (83\%), siswa menulis pelajaran yang disampaikan guru sebanyak 26 siswa (87\%), siswa mampu mempraktekkan pelajaran sesuai dengan permintaan guru sebanyak 24 siswa (80\%).

2) Observasi siswa mengenai minat pemanfaatan waktu belajar terdiri dari 4 deskriptor, yaitu siswa menyusun kegiatan belajar sehari - hari sebanyak 24 siswa (80\%), siswa tidak suka berlama - lama di luar kelas 
pada saat istirahat sudah berakhir sebanyak 26 siswa $(87 \%)$, siswa memanfaatkan waktu istirahat untuk mendiskusikan pelajaran dengan temannya sebanyak 23 siswa (77\%), siswa tidak suka bermain sebelum tugasnya selesai sebanyak 27 siswa $(90 \%)$.

3) Observasi siswa mengenai minat mengulang pelajaran kembali terdiri dari 4 deskriptor, yaitu siswa membaca buku pelajaran setelah pelajaran berakhir sebanyak 24 siswa (80\%), siswa membuat ringkasan setelah pelajaran berakhir sebanyak 26 siswa $(87 \%)$, siswa mengingat apa yang sudah dipelajari sebanyak 28 siswa (93\%), siswa mengerjakan PR sebanyak 30 siswa (100\%).

4) Observasi siswa mengenai minat menyenangi pelajaran terdiri dari 4 deskriptor, yaitu siswa cepat datang ke sekolah sebanyak 29 siswa (97\%), siswa menyediakan perlengkapan untuk belajar sebanyak 30siswa $(100 \%)$, siswa memberi tanda pada hal - hal yang penting sebanyak 24 siswa $(80 \%)$, siswa selalu bersemangat pada saat mengikuti pembelajaran sebanyak 22 siswa $(73 \%)$

5) Observasi siswa mengenai minat aktif di dalam kelas terdiri dari 4 deskriptor, yaitu siswa selalu menulis dan mencatat pelajaran penting sebanyak 27 siswa (90\%), siswa sering bertanya sebanyak 24 siswa (80\%), siswa sering menjawab pertanyaan sebanyak 24 siswa (80\%), siswa selalu mengeluarkan pendapat dalam diskusi kelompok sebanyak 26 siswa $(87 \%)$.

Dari hasil observasi siklus II pada tabel di atas telah mencapai taraf persentase yang cukup tinggi.

\section{Refleksi}

Hasil observasi siklus II yang dilakukan oleh guru dari 30 jumlah siswa, yakni diperoleh nilai sebagai berikut : Siswa yang berminat sebanyak 20 orang dengan persentase $67 \%$. Dari hasil observasi siswa yang telah dilakukan pada siklus II, maka hasilnya adalah : 1) Guru sudah menguasai kelas dengan baik, karena guru sudah lebih menguasai bahan ajar, 2) siswa sudah aktif dalam menjawab/menyelesaikan tugas yang diberikan guru, karena guru sudah menguasai model pembelajaran dan menggunakan media gambar, 3) di dalam proses pembelajaran, guru sudah dapat menggunakan waktu yang efektif sehingga tujuan pembelajaran tercapai, 4) aktivitas guru dalam bertanya kepada siswa, sudah cukup tinggi, memperhatikan dan membimbing siswa sudah meningkat, karena interaksi antara guru dan siswa pada saat proses belajar mengajar berlangsung dengan cukup baik, 5) tahap kegiatan akhir, guru sudah dapat melaksanakan penilaian pembelajaran dan lebih sempurna lagi dalam merangkum isi pelajaran. 
Berdasarkan hasil observasi yang telah dilakukan pada pelajaran PKn pokok bahasan politik luar negeri di siklus II sudah sangat baik dalam kegiatan pembelajaran. Peningkatan minat belajar siswa melalui penggunaan model pembelajaran kooperatif tipe tari bambu telah tercapai dengan baik, sehingga tidak perlu lagi dilanjutkan ke siklus berikutnya.

Tabel 2.

Peningkatan Nilai Rata - Rata Siswa

\begin{tabular}{|c|c|c|c|}
\hline \multirow{2}{*}{ No. } & \multirow{2}{*}{ Observasi } & \multicolumn{2}{|c|}{ Nilai Rata - Rata } \\
\cline { 3 - 4 } & & Jumlah & $\%$ \\
\hline 1 & Siklus I & 44 & 55 \\
\hline 2 & Siklus II & 69 & 87 \\
\hline
\end{tabular}

\section{KESIMPULAN}

Berdasarkan hasil dan pembahasan penelitian, dapat diperoleh kesimpulan bahwa dengan menggunakan model pembelajaran kooperatif tipe tari bambu, dapat meningkatkan minat belajar siswa pada pokok bahasan politik luar negeri di Kelas VIB SD Negeri 060930 Medan Johor. Maka dalam hal ini guru dapat membuat kesimpulan sebagai berikut:

1. Dengan menggunakan model pembelajaran kooperatif tipe tari bambu, dapat meningkatkan minat belajar siswa dalam mata pelajaran PKn pada pokok bahasan politik luar negeri di Kelas VIB SD Negeri 060930 Medan Johor.

2. Pada observasi minat belajar siswa siklus I rata - rata nilai keseluruhan yang diperoleh hanya mencapai 44, persen (\%) yang diperoleh sebesar $55 \%$. Dari hasil hitungan observasi siswa siklus I masih tergolong rendah. Pada siklus II rata - rata nilai keseluruhan yang diperoleh yaitu sebesar 69, persen (\%) yang diperoleh adalah sebesar 87\%. Pada siklus II dapat dilihat bahwa guru sudah meningkatkan penggunaan model pembelajaran kooperatif tipe tari bambu dengan baik dan perilaku belajar siswa sudah meningkat.

\section{Saran}

Berdasarkan hasil penelitian dan kesimpulan yang dikemukakan diatas, maka guru memberi beberapa saran, yaitu:

1. Agar para kepala sekolah melakukan supervisi dengan pembaharuan pembelajaran PKn serta pendalaman penggunaan model pembelajaran kooperatif tipe Tari Bambu.

2. Agar para guru SD Negeri 060930 Medan Johor menerapkan penggunaan model pembelajaran kooperatif tipe Tari Bambu sebagai salah satu alternatif dalam meningkatkan minat belajar siswa. 
3. Agar pihak sekolah SD Negeri 060930 Medan Johor. semakin memaksimalkan penerapan model pembelajaran kooperatif tipe Tari Bambu yang berfokus pada memaksimalkan aktivitas belajar siswa untuk meningkatkan kualitas pembelajaran.

4. Guru dan orang tua saling bekerjasama dalam meningkatkan hasil belajar siswa.

5. Bagi para pembaca, penulis mengharapkan agar benar-benar mengembangkan metode pembelajaran ini dalam pembaharuan pendidikan.

\section{REFERENSI}

Arikunto, Suharsimi. (2006). Prosedur Penelitian Suatu Pendekatan Praktik. Jakarta: PT. Bumi Aksara.

Bahri, Syaiful, dkk. (2006). Strategi Belajar Mengajar. Jakarta: PT. Rineka Cipta.

Djaali. (2006). Psikologi Pendidikan. Jakarta: PT. Bumi Aksara.

Isjoni. (2009). Pembelajaran Kooperatif. Yogyakarta: Pustaka Pelajar.

Lie, Anita. (2010). Cooperative Learning. Jakarta: GRASINDO.

Sanjaya, Wina. (2008). Strategi Pembelajaran. Bandung: Kencana.

Slameto. (2010). Belajar dan Faktor-faktor yang Mempengaruhinya. Jakarta: PT. Rineka Cipta.

Syah, Muhibbin. (2010). Psikologi Pendidikan. Bandung: Remaja Rosdakarya. 